\title{
PENGEMBANGAN LEMBAR KERJA PESERTA DIDIK MODEL DISCOVERY LEARNING BERBASIS MASALAH KONTEKSTUAL PADA MATERI OPERASI ALJABAR FUNGSI
}

\author{
Dinny Meikasari ${ }^{1}$, Nur Izzati² \\ 1,2Program Studi Pendidikan Matematika, FKIP Universitas Maritim Raja Ali Haji Kepulauan Riau \\ E-mail: dinnymeika88@gmail.com
}

\begin{abstract}
The purpose of this study was to develop a student worksheet model of contextual problem-based learning discovery. This research is a type of research and development using the $4 \mathrm{D}$ model. This model has 4 stages namely Define, Design, Development, and Disseminate. A total of 22 students of class XI of Fashion Management at SMK Negeri 2 Tanjungpinang were involved in the study as test subjects. Data collection techniques consisted of validation of material experts and media experts as well as student questionnaire responses. The instrument used consisted of a validation sheet and a questionnaire. Data were analyzed using the MSR (Summated Ratings Method) method. The results of the calculation of material experts were $86,08 \%$, media experts $98,18 \%$, and the questionnaire responses of students reached $86,45 \%$. Obtained from the two results of the three products into a very possible category. Therefore, the students' worksheets that are developed are very appropriate to be used in the learning process.
\end{abstract}

Keywords: Student Worksheets, Development, Discovery Learning, Algebraic Operation Functions

\begin{abstract}
ABSTRAK
Tujuan dari penelitian ini adalah untuk mengembangkan produk Lembar Kerja Peserta Didik (LKPD) model discovery learning berbasis masalah kontekstual. Penelitian ini termasuk jenis penelitian dan pengembangan dengan menerapkan model 4D. Model ini memiliki 4 tahapan yaitu Define, Design, Development dan Disseminate. Sebanyak 22 peserta didik kelas XI Tata Busana SMK Negeri 2 Tanjungpinang dilibatkan dalam penelitian sebagai subjek uji coba. Teknik pengumpulan data terdiri dari validasi ahli materi dan ahli media serta angket respon peserta didik. Instrumen yang digunakan berupa lembar validasi dan angket. Analisis data menggunakan Method of Summated Ratings (MSR). Hasil penghitungan penilaian ahli materi sebesar $86,08 \%$, ahli media $98,18 \%$, dan angket respon peserta didik sebesar $86,45 \%$. Dilihat dari ketiga hasil persentase tersebut maka produk pengembangan masuk kedalam kategori sangat layak. Oleh karena itu, lembar kerja peserta didik yang dikembangan ini sangat layak untuk digunakan dalam proses pembelajaran.
\end{abstract}

Kata Kunci: Lembar Kerja Peserta Didik, Pengembangan, Discovery Learning, Operasi Aljabar Fungsi

\section{PENDAHULUAN}

Pendidikan memiliki kontribusi yang cukup signifikan dalam menaikkan derajat manusia (Pratiwi, 2017). Melalui pendidikan, seseorang dapat menerima dan memberikan wawasan yang dimilikinya kepada orang lain. Seperti bunyi dari hukum dasar tertulis bangsa Indonesia yaitu mencerdaskan kehidupan bangsa. Tujuan negara Indonesia saat ini adalah mampu mewujudkan pendidikan yang berkualitas.

\footnotetext{
* Copyright (c) 2020 Dinny Meikasari dan Nur Izzati

This work is licensed under a Creative Commons Attribution-ShareAlike 4.0 International License.
} 
Khazanah Pendidikan Islam, Vol. 2 No. 2: 68-76

Pengembangan Lembar Kerja Peserta Didik Model Discovery Learning Berbasis Masalah Kontekstual pada Materi Operasi Aljabar Fungsi

Dinny Meikasari dan Nur Izzati

Pemerintah telah melakukan berbagai upaya untuk mewujudkan pendidikan bermutu, salah satunya melalui pembaharuan kurikulum. Kurikulum nasional terbaru adalah kurikulum 2013 yang telah mengalami revisi di tahun 2017. Dalam kurikulum 2013 revisi 2017, salah satu mata pelajaran umum yang selalu diajarkan disetiap jenjang sekolah adalah matematika.

Pada Permendikbud No.36 Tahun 2018 dijelaskan bahwa bidang pelajaran umum yang salah satunya adalah matematika, disebutkan bahwa matematika adalah mata pelajaran yang tujuannya mengembangkan kompetensi kognitif, afektif, dan psikomotorik dari peserta didik sebagai bekal agar mampu terjun ke dalam kehidupan bermasyarakat (Siagian, 2015). Tapi kondisi yang terjadi adalah banyak peserta didik belum mengembangkan kompetensi-kompetensi yang dituntut, karena matematika masih dianggap sulit oleh peserta didik. Seperti yang diungkapkan oleh Tresnaningsih (2013) bahwa dalam proses pembelajaran mata pelajaran matematika masih ada siswa menganggap matematika sulit, membosankan, merupakan momok. Padahal, jika dilihat dari sisi lainnya, salah satu subjek penting dalam kehidupan sehari-hari adalah matematika. Boleh dikatakan setiap bidang dalam kehidupan saat ini berkaitan dengan matematika.

Hal yang dapat dilakukan untuk menghilangkan rasa bosan peserta didik serta menanamkan mindset bahwa matematika dalah pelajaran yang penting adalah dengan adanya media pembelajaran. Media pembelajaran yang dapat memudahkan proses pengajaran salah satunya ialah lembar kerja peserta didik seperti yang dikatakan oleh Indriyani (2019) bahwa media pembelajaran merupakan alat atau sarana yang membantu proses jalannya pembelajaran supaya lebih mudah dan efisien. Media pembelajaran yang dapat memudahkan proses pembelajaran adalah lembar kerja peserta didik. Tugas pendidik salah satunya adalah menyediakan lembar kerja peserta didik yang layak digunakan sesuai kebutuhan didalam kelas

Dalam menyediakan lembar kerja peserta didik yang layak digunakan, tentu diperlukan model pembelajaran yang tepat. Model pembelajaran digunakan untuk mendukung konten dari lembar kerja peserta didik. Ada banyak model pembelajaran yang tersedia, tapi salah satu yang sesuai dengan kurikulum 2013 adalah model pembelajaran discovery learning. Berdasarkan penelitian yang dilakukan oleh Yusri (2018), discovery learning merupakan suatu proses belajar yang mana konsep pembelajaran itu tidak lansung disajikan, tetapi siswa diminta untuk mendapatkan sendiri konsepnya sehingga siswa dapat menemukan konsep/informasi baru. Didalam model pembelajaran ini, mencakup tahapan-tahapan yang akan mengorganisir peserta didik menemukan konsep secara mandiri. Menurut Syah (1995) model discovery learning terdiriri dari 6 tahapan yaitu , (1) Stimulation atau pemberian rangsangan (2) Problem Statement yaitu mengidentifikasi sebanyak mungkin masalah yang relevan dengan bahan pelajaran, kemudian salah satunya dipilih dan dirumuskan dalam bentuk jawaban sementara (3) Data Collection, yaitu mengumpulkan informasi sebanyak-banyaknya yang relevan untuk membuktikan benar atau tidaknya jawaban. (4) Data Processing, yaitu mengolah data dan informasi yang telah diperoleh kemudia ditafsirkan. (5) Verification yaitu melakukan pemeriksaan untuk membuktikan benar atau tidaknya jawaban yang telah ditetapkan dan dihubungkan dengan hasil data processing. (6) Generalization yaitu menarik sebuah simpulan dalam Akbar (2018).

Materi pelajaran matematika kelas XI SMK yang sesuai untuk diangkat menjadi sebuah LKPD bermodel discovery learning adalah materi operasi aljabar fungsi. Materi ini mencakup 4 operasi dalam aljabar yaitu pengurangan, penjumlahan, perkalian, dan pembagian. Permasalahan yang diangkat dari materi ini menggunakan permasalahan kontekstual. Menurut Maryati (2016) bahwa tujuan dari permasalahan kontekstual ini membantu guru untuk mengaitkan materi pelajaran dengan kehidupan nyata dan memotivasi siswa untuk mengaitkan pengetahuan yang dipelajarinya dengan kehidupan 
Khazanah Pendidikan Islam, Vol. 2 No. 2: 68-76

Pengembangan Lembar Kerja Peserta Didik Model Discovery Learning Berbasis Masalah Kontekstual pada Materi Operasi Aljabar Fungsi

Dinny Meikasari dan Nur Izzati

mereka. Karena masalah yang seringkali peserta didik temui dalam kehidupan nyata lebih mudah dipahami dan sangat membantu mereka dalam menemukan konsep penyelesaian.

Beberapa penelitian tentang Pengembangan Lembar Kerja Peserta Didik oleh Sasmito \& Mustadi (2015) yang berbasis kepada Pendidikan karakter, Penelitian yang dilakukan oleh Sari, Prasetyo, \& Wibowo (2017) pengembangan dengan berbasiskan model project serta penelitian tentang pengembangan lembar kerja perserta didik oleh (Noprinda \& Soleh 2019) Berbasis Higher Order Thinking Skill (HOTS). Pada penelitian ini penulis mengambil sisi berbeda dalam pengembangan lembar kerja peserta didik dimana disini peneliti berbasis masalah kontekstual pada materi operasi aljabar fungsi. Penelitian lainnya yaitu penelitian oleh Maimunah, Izzati, \& Dwinata (Maimunah, Izzati, \& Dwinata, 2019). Persamaan dari penelitian ini adalah sama-sama mengembangkan lembar kerja peserta didik. Perbedaan terletak pada model pengembangan yang digunakan. Penelitian relevan menggunakan model ADDIE terbatas yaitu ADD (analysis, design, development), sedangkan penelitian ini menggunakan model 4D (define, design, development, disseminate). Hasil penelitian relevan menunjukkan bahwa LKPD yang dikembangkan memenuhi kriteria valid dengan penilaian yang diberikan oleh masing-masing ahli dalam kategori baik.

Berdasarkan uraian di atas, peneliti tertarik melakukan penelitian yang berjudul pengembangan lembar kerja peserta didik menggunakan model discovery learning berbasis masalah kontekstual pada materi operasi aljabar fungsi. Rumusan masalah dalam penelitian ini yaitu; bagaimanakah pengembangan lembar kerja peserta didik model discovery learning berbasis masalah kontekstual pada materi operasi aljabar fungsi kelas XI SMK dan kelayakan lembar kerja peserta didik tersebut berdasarkan penilaian ahli media, ahli materi, dan peserta didik? Sesuai dengan rumusan masalah, maka penelitian ini bertujuan untuk mendeskripsikan pengembangan lembar kerja peserta didik model discovery learning berbasis masalah kontekstual pada materi operasi aljabar fungsi kelas XI SMK yang layak berdasarkan penilaian ahli media, ahli materi, dan peserta didik.

\section{METODE PENELITIAN}

Penelitian ini merupakan penelitian dan pengembangan. Tujuan dari penelitian ini adalah mengembangkan lembar kerja peserta didik model discovery learning berbasis masalah kontekstual pada materi operasi aljabar fungsi kelas XI SMK. Penelitian yang dilakukan menerapkan model pengembangan 4D yang dikemukakan oleh Thiagarajan dalam Ansari (2010). Adapun model pengembangan tersebut terdiri dari empat tahapan pengembangan yaitu define, design, development, dan disseminate.

Tahap define atau disebut juga tahap pendefinisian. Pada tahap ini dilakukan analisis kebutuhan akan penelitian, yaitu analisis kurikulum, analisis media pembelajaran, analisis peserta didik, serta dilanjutkan analisis konsep akan terlebih dahulu dilakukan pada tahap awal ini. Tujuan dari tahap ini untuk melihat kesenjangan yang ada di SMK Negeri 2 Tanjungpinang. Permasalahannya yaitu tentang kurangnya penggunaan media pembelajaran ketika pembelajaran berlangsung dan keunikan dari peserta didik yang cenderung menyenangi pembelajaran dengan konsep penemuan mandiri.

Tahap design atau tahap perancangan. Ditahap inilah draft yang akan dikembangkan mulai dipersiapkan dan dikerjakan. Tahap perancangan ini terdiri dari penyusunan format LKPD bermodel discovery learning berbasis masalah kontekstual. Harapannya dengan adanya tahap perancangan ini, penampilan, isi, dan format LKPD akan tersusun secara sistematis memenuhi persyaratan kurikulum 2013. 
Khazanah Pendidikan Islam, Vol. 2 No. 2: 68-76

Pengembangan Lembar Kerja Peserta Didik Model Discovery Learning Berbasis Masalah Kontekstual pada Materi Operasi Aljabar Fungsi

Dinny Meikasari dan Nur Izzati

Selanjutnya tahap development. Pada tahap ini, draf LKPD yang dikembangkan divalidasi oleh ahli dan sudah menghasilkan lembar kerja peserta didik model discovery learning berbasis masalah kontekstual, yang sudah direvisi berdasarkan saran ahli. Penilaian validasi ini dilakukan oleh ahli perangkat pembelajaran, yakni guru senior pada mata pelajaran matematika SMK Negeri 2 Tanjungpinang. Tahap disseminate atau tahapan penyebarluasan. Produk yang sudah dikembangkan, akan disebarluaskan pada tahapan ini. Untuk menghemat biaya, tahap penyebarluasan dilakukan dengan menyebarkan lembar kerja peserta didik berbentuk soft file pada guru yang berbeda namun disekolah yang sama.

Penelitian dilakukan di salah satu sekolah kejuruan yaitu SMK Negeri 2 Tanjungpinang saat minggu ketiga bulan November 2019 di kelas XI Tata Busana 1 dengan subjek penelitian sebanyak 22 peserta didik. Penelitian ini menggunakan instrumen penelitian dalam bentuk lembar validasi dan angket. Lembar validasi diisi oleh guru mata pelajaran sebagai validator dan angket respon oleh peserta didik.. Selanjutnya data yang sudah didapatkan akan dianalisis dengan teknik analisis data yang dikembangkan oleh Gable. Disebut dengan MSR (Method of Summated Ratings) Didalam metode ini respon yang diberikan oleh responden akan dikelompokkan dan diletakkan dalam suatu kontinum, kemudian skor setiap pernyataan ditentukan berdasarkan distribusi respon (Azwar, 2009; Izzati, 2012). Persentase kelayakan dapat diperoleh dengan menggunakan rumus berikut:

$$
\text { Persentase }=\frac{\text { Jumlah } \text { skor hasil validasi }}{\text { skor tertinggi }} \times 100 \%
$$

Setelah didapatkan hasil perhitungan persentase, selanjutnya menentukan tingkat kelayakan produk yang dikembangkan dengan berpedoman pada kriteria kelayakan yang dikemukakan oleh Arikunto (dalam Ernawati \& Sukardiyono, 2017). Kriteria kelayakan tersebut dapat dilihat pada Tabel 1.

Tabel 1. Kriteria Kelayakan

\begin{tabular}{|c|c|}
\hline Penilaian & Kriteria \\
\hline$<21 \%$ & Sangat Tidak Layak \\
\hline $21 \%-40 \%$ & Tidak Layak \\
\hline $41 \%-60 \%$ & Cukup Layak \\
\hline $61 \%-80 \%$ & Layak \\
\hline $81 \%-100 \%$ & Sangat Layak \\
\hline
\end{tabular}

Menurut kriteria kelayakan pada Tabel 1 tersebut, produk yang dikembangkan dikatakan layak jika persentase penilaian menunjukkan hasil $\geq 61 \%$, setelah dilakukan pembulatan ke satuan terdekat sesuai aturan pembulatan bilangan jika hasil perhitungan persentanse bukan bilangan bulat.

\section{HASIL DAN PEMBAHASAN}

Penelitian ini dilaksanakan di SMK Negeri 2 Tanjungpinang dengan subjek penelitian peserta didik kelas XI Tata Busana 1 sebanyak 22 peserta didik. Penelitian ini menghasilkan lembar kerja peserta didik model discovery learning berbasis masalah kontekstual pada materi operasi aljabar fungsi kelas XI SMK yang layak dilihat dari penilaian ahli materi dan ahli media serta penilaian peserta didik. Penelitian ini 
Khazanah Pendidikan Islam, Vol. 2 No. 2: 68-76

Pengembangan Lembar Kerja Peserta Didik Model Discovery Learning Berbasis Masalah Kontekstual pada Materi Operasi Aljabar Fungsi

Dinny Meikasari dan Nur Izzati

dilakukan minggu ketiga bulan November 2019. Penjelasan dari tahap-tahap pengembangan sebagai berikut:

\section{Tahap Define}

Tahapan Define atau pendefinisian yaitu analisis kurikulum, analisis media pembelajaran, analisis peserta didik, dan juga analisis konsep akan dilakukan. Tahapan ini bermaksud untuk melihat kesenjangan yang ada di SMK Negeri 2 Tanjungpinang. Setelah dilakukan analisis kurikulum dengan cara wawancara langsung didapatkan bahwa SMK Negeri 2 menggunakan Kurikulum 2013 revisi 2017.

Selanjutnya adalah menganalisis media pembelajaran. Analisis ini berfungsi agar peneliti mengetahui saat proses pembelajaran media apa saja yang digunakan. Hasil observasi menunjukkan bahwa hanya buku paket matematika yang digunakan sebagai media pembelajaran dan dipinjamkan saat hanya pembelajaran berlangsung kemudian langsung dikembalikan ke perpustakaan sekolah apabila sudah habis jam pelajaran. Analisis selanjutnya yaitu analisis peserta didik. Analisis ini guna melihat kebutuhan dalam pengembangan lembar kerja peserta didik model discovery learning berbasis masalah kontekstual. Proses belajar dengan menggunakan lembar kerja peserta didik lebih digemari oleh peserta didik karena mereka bisa bekerja secara mandiri dan tentunya dapat dibawa pulang kerumah untuk mengulang kembali pembelajaran disekolah. Hal ini didapatkan saat peneliti melakukan wawancara tak berstruktur dengan peserta didik.

Analisis konsep yaitu mengidentifikasi seperti apa konsep lembar kerja yang dikembangkan agar dapat mencapai batas dimana peserta didik mampu mendapatkan konsep secara mandiri.

\section{Tahap Design}

Tahapan ini bertujuan dalam perancangan lembar kerja peserta didik model discovery learning berbasis masalah kontekstual pada materi operasi aljabar fungsi kelas XI SMK. Didalam LKPD terdapat beberapa bagian yaitu cover, kompetensi dasar, tujuan pembelajara, materi, serta evaluasi. Cover LKPD disajikan dalam Gambar 1:

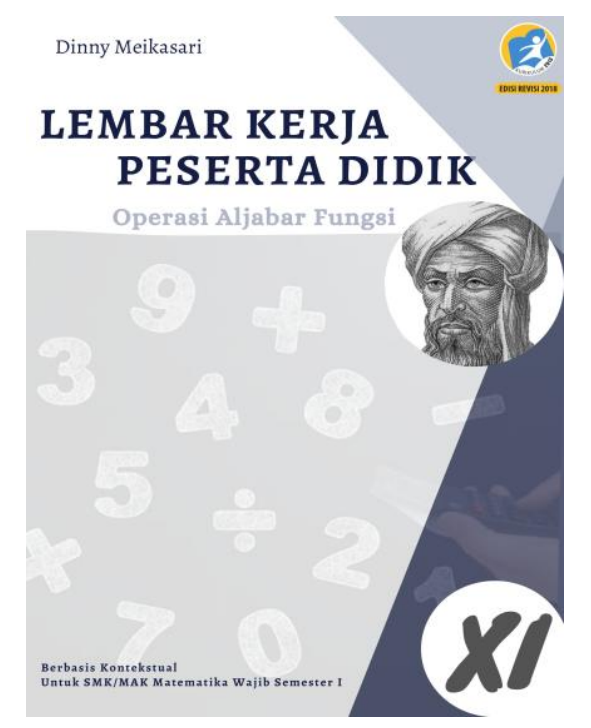

Gambar 1. Cover Lembar Kerja Peserta Didik 
Khazanah Pendidikan Islam, Vol. 2 No. 2: 68-76

Pengembangan Lembar Kerja Peserta Didik Model Discovery Learning Berbasis Masalah Kontekstual pada Materi Operasi Aljabar Fungsi

Dinny Meikasari dan Nur Izzati

Peneliti menggunakan beberapa aplikasi berbeda saat merancang LKPD ini. Diantaranya aplikasi Pinterest untuk mendapatkan gambar yang bagus dan menarik, aplikasi Canva Premium saat merancang cover dan aplikasi Microsoft Word 2010 saat merancang isi dari LKPD. Selain itu, didalam LKPD juga disisipkan karakteristik model discovery learning berbasis masalah kontekstual disajikan dalam Gambar 2 sebagai berikut:

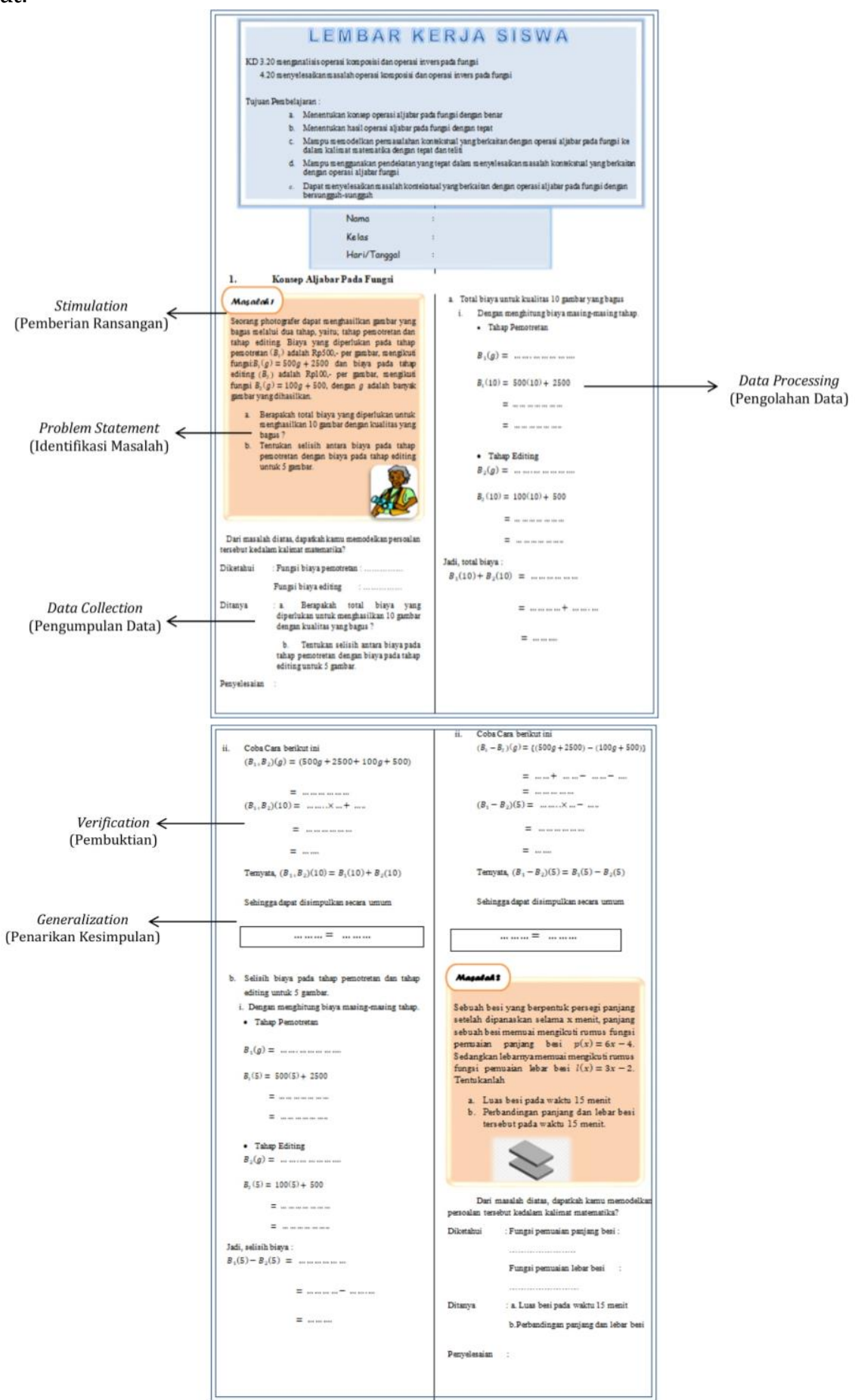

Gambar 2. Penyisipan Karakteristik Discovery Learning 
Khazanah Pendidikan Islam, Vol. 2 No. 2: 68-76

Pengembangan Lembar Kerja Peserta Didik Model Discovery Learning Berbasis Masalah Kontekstual pada Materi Operasi Aljabar Fungsi

Dinny Meikasari dan Nur Izzati

\section{Tahap Development}

Pada tahapan ini, tujuan utamanya adalah mengahasilkan lembar kerja peserta didik model discovery learning berbasis masalah kontekstual pada materi operasi aljabar fungsi kelas XI SMK melalui instrumen penelitian berupa angket validasi ahli media dan ahli materi serta angket respon peserta didik. Evaluasi dalam angket adalah penilaian peserta didik yang terbagi menjadi desain dan manfaat lembar kerja peserta didik. Setelah dianalisis, hasil penilaian dari ahli materi sebesar 86,08\% dan masuk kedalam kriteria sangat baik. Selanjutnya analisis dari ahli media yang didalamnya mencakup desain lembar kerja peserta didik menunjukkan persentase sebesar $98,18 \%$ sehingga dapat disimpulkan penilaian dari ahli media juga sangat layak dengan beberapa pendapat perbaikan dari ahli yang digunakan sebagai referensi dalam pengembangan lembar kerja peserta didik, perbaikan ini dapat dilihat pada Tabel 2 .

\section{Tabel 2. Perbedaan sebelum dan sesudah revisi}

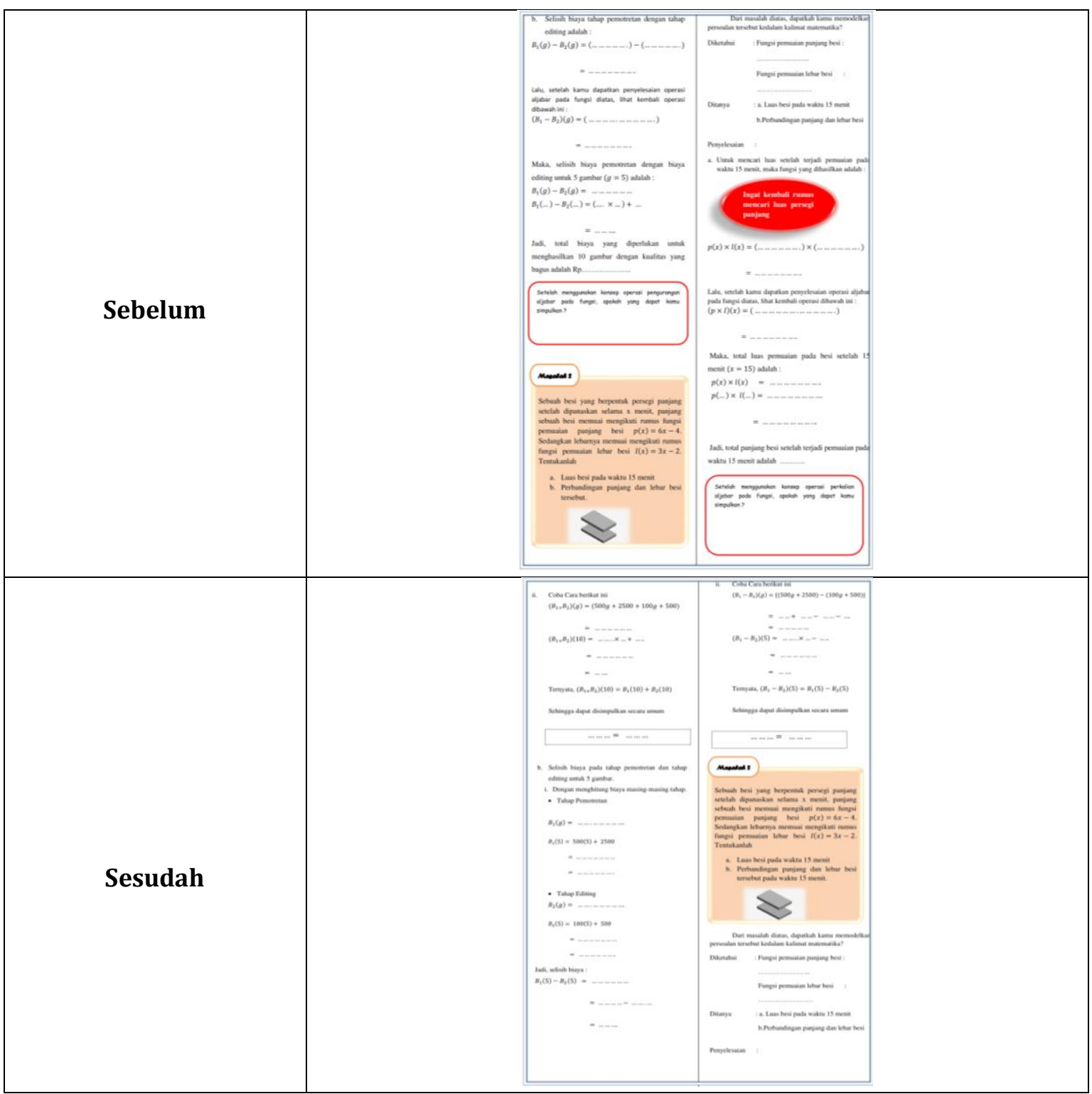


Khazanah Pendidikan Islam, Vol. 2 No. 2: 68-76

Pengembangan Lembar Kerja Peserta Didik Model Discovery Learning Berbasis Masalah Kontekstual pada Materi Operasi Aljabar Fungsi

Dinny Meikasari dan Nur Izzati

Penilaian ahli materi mencakup kesesuaian dengan KI dan KD, kebenaran substansi materi pembelajaran, kesesuaian dengan karakteristik discovery learning, kemutakhiran materi, manfaat penyajian materi, kejelasan tujuan, dan pemberian motivasi. Sedangkan komponen penilaian ahli media memuat tentang penggunaan font, jenis, dan ukuran, layout atau tata letak, ilustrasi, gambar, foto, dan desain tampilan. Masukan dari ahli yaitu agar bagian penemuan konsep makin diperjelas kembali, dengan cara diberikan kotak sehingga peserta didik lebih fokus perhatiannya ke dalam kotak yang telah mereka lengkapi.

Tabel 3. Keseluruhan hasil perhitungan validasi ahli materi dan ahli media

\begin{tabular}{|l|l|c|}
\hline \multicolumn{1}{|c|}{ No. } & \multicolumn{1}{|c|}{ Aspek Penilaian } & Persentase \\
\hline 1 & Validasi Ahli Materi & $86,08 \%$ \\
\hline 2 & Validasi Ahli Media & $98,18 \%$ \\
\hline \multicolumn{2}{|c|}{ Rata-rata Persentase } & $\mathbf{9 2 , 1 3 \%}$ \\
\hline
\end{tabular}

Berdasarkan Tabel 3, rata-rata hasil keseluruhan validasi sebesar 92,13\% dengan kriteria penilaian sangat layak digunakan. Uji coba dilakukan pada bulan November 2019 dikelas XI Tata Busana SMK Negeri 2 Tanjungpinang dengan peserta didik berjumlah 22. Peserta didik diberikan angket respon oleh peneliti, dan persentase rata-rata yang diperoleh sebesar $86,45 \%$ dan memiliki kriteria yang sangat layak. Persentase tersebut menyimpulkan bahwa produk yang dikembangkan sangat layak digunakan dalam proses pembelajaran.

\section{Tahap Disseminate}

Pada tahapan ini, produk yang dihasilkan disebarkan kepada guru yang berbeda tetapi tetap disekolah yang sama. Karena keterbatasan waktu dan biaya, produk disebar dalam bentuk soft file melalauiflashdisk. Tujuannya agar dapat digunakan kembali untuk kelas yang berbeda.

\section{SIMPULAN}

Hasil yang diperoleh dari penelitian ini adalah persentase kelayakan lembar kerja peserta didik dari ahli materi sebesar $86,08 \%$, ahli materi $98,18 \%$, serta angket respon peserta didik menunjukkan rerata persentase mencapai $86,45 \%$. Dari ketiga penilaian tersebut termasuk kedalam kriteria sangat layak. Oleh sebab itu, lembar kerja peserta didik model discovery learning berbasis masalah kontekstual pada materi operasi aljabar fungsi kelas XI SMK sangat layak digunakan.

\section{DAFTAR PUSTAKA}

Akbar, I. (2018). Pengembangan lembar kerja peserta didik berbasis model pembelajaran discovery learning pada siswa MTSn Stabat T.P 2017/2018 (Universitas Muhammadiyah Sumatera Utara). https://doi.org/10.1017/CB09781107415324.004

Ansari, T. (2010). Model Pembelajaran terpadu konsepstrategi, dan implementasinya dalam kurikulum Tingkat Satuan Pendidikan. Kuala Lumpur: Kemetrian Pengajaran Malaysia, 189.

Azwar, S. (2009). Dasar-Dasar Psikometri. Yogyakarta: Pustaka Pelajar.

Ernawati, I., \& Sukardiyono, T. (2017). Uji kelayakan media pembelajaran interaktif pada mata pelajaran administrasi server. Elinvo (Electronics, Informatics, and Vocational Education), 2(2), 204-210. https://doi.org/10.21831/elinvo.v2i2.17315

Indriyani, L. (2019). Pemanfaatan Media Pembelajaran Dalam Proses Belajar Untuk Meningkatkan Kemampuan Berpikir Kognitif Siswa. Seminar Nasional Pendidikan FKIP, 2(1), 25. 
Khazanah Pendidikan Islam, Vol. 2 No. 2: 68-76

Pengembangan Lembar Kerja Peserta Didik Model Discovery Learning Berbasis Masalah Kontekstual pada Materi Operasi Aljabar Fungsi

Dinny Meikasari dan Nur Izzati

Kemdikbud. (2018). Konsep dan implementasi kurikulum 2013. In Permendikbud.

Maimunah, Izzati, N., \& Dwinata, A. (2019). Pengembangan lembar kerja peserta didik berbasis realistic mathematics education dengan konteks kemaritiman untuk peserta didik SMA kelas XI. Jurnal Gantang, 4(2), 133-142.

Maryati, I. (2016). Social Entrepreneurship Tournament for High School Students. Aplikatif, 6, 129140.

Noprinda, C. T., \& Soleh, S. M. (2019). Pengembangan Lembar Kerja Peserta Didik (LKPD) Berbasis Higher Order Thinking Skill (HOTS). Indonesian Journal of Science and Mathematics Education, 2(2), 168-176.

Pratiwi, N. K. (2017). Pengaruh Tingkat Pendidikan, Perhatian Orang Tua, Dan Minat Belajar Siswa Terhadap Prestasi Belajar Bahasa Indonesia Siswa Smk Kesehatan Di Kota Tangerang. Pujangga, 1(2), 31.

Sari, K. A., Prasetyo, Z. K., \& Wibowo, W. S. (2017). Pengembangan lembar kerja peserta didik ipa berbasis model project based learning untuk meningkatkan keterampilan kolaborasi dan komunikasi peserta didik kelas vii. Jurnal Pendidikan Ilmu Pengetahuan Alam-S1, 6(8), 461467.

Sasmito, L. F., \& Mustadi, A. (2015). Pengembangan lembar kerja peserta didik tematik-integratif berbasis pendidikan karakter pada peserta didik sekolah dasar. Jurnal Pendidikan Karakter, (1).

Siagian, R. E. F. (2015). Pengaruh minat dan kebiasaan belajar siswa terhadap prestasi belajar matematika. Formatif: Jurnal Ilmiah Pendidikan MIPA, 2(2).

Syah, M. (1995). Psikologi pendidikan suatu pendekatan baru. Bandung: remaja rosdakarya.

Tresnaningsih, S. (2013). Pembelajaran Matematika Dalam Implementasi Kurikulum 2013. Skripsi, $1-14$.

Yusri, A. Y. (2018). Pengaruh Model Pembelajaran Problem Based Learning terhadap Kemampuan Pemecahan Masalah Matematika Siswa Kelas VII di SMP Negeri Pangkajene. Mosharafa: Jurnal Pendidikan Matematika, 7(1), 51-62. 